\title{
Occurrence of Domestic Violence among Women and its Impact on Oral Health in Jodhpur City
}

\author{
${ }^{1}$ Preksha Pewa, ${ }^{2}$ Susan Thomas, ${ }^{3}$ Rushabh Dagli, ${ }^{4}$ Jitendra Solanki, ${ }^{5}$ Geetika Arora, ${ }^{6}$ Bharath Garla
}

\begin{abstract}
Background: This study had a two objectives to determine the prevalence of domestic violence and to know the impact of the same on the oral health.
\end{abstract}

Materials and methods: An observational cross-sectional study was done in Jodhpur, Rajasthan; among 150 married women of 18 to 60 years of age using a predesigned pretested proforma from 18th January 2014 to 27th February 2014. Pretested semistructured open-ended questionnaire used for collecting the data from the study subjects. Pearson's Chisquare test and $p$-value were used to calculated the occurrence and impact of domestic violence on oral health among women.

Results: The most common form of domestic violence found was physical abuse $(54.7 \%)$ followed by emotional abuse $(20.0 \%)$ and financial abuse $(14.0 \%)$. The most important risk factor was alcoholism followed by literacy status and having a girl child. Study shows that physical abuse is more in graduate than lower level of educational females. Females living in urban area show highest frequency of physical abuse than those living in rural area. Injury to the face were highly reported $(38.7 \%)$ followed by injury to lip (13.3\%) and nose fracture/bleeding nose $(9.3 \%)$.

Conclusion: Government has to take stringent action to prevent domestic violence by making women more self-reliant especially by making women more literate and more financially independent.

Keywords: Domestic violence, Emotional abuse, Physical abuse.

How to cite this article: Pewa P, Thomas S, Dagli R, Solanki J, Arora G, Garla B. Occurrence of Domestic Violence among Women and its Impact on Oral Health in Jodhpur City. J Contemp Dent Pract 2015;16(3):227-233.

Source of support: Nil

Conflict of interest: None

\section{INTRODUCTION}

Domestic violence is defined as:

'Any incident of threatening behavior, violence or abuse between adults who are, or who have been, in a

\footnotetext{
${ }^{1-6}$ Department of Public Health Dentistry, Vyas Dental College and Hospital, Jodhpur, Rajasthan, India
}

Corresponding Author: Preksha Pewa, Postgraduate Student, Department of Public Health Dentistry, C-7 Shiv Om Shakti, Pewa Nagar, Near Subham Farm House, Pal Road Jodhpur, Rajasthan, India, Phone: 09950837778, e-mail: ppewa1988@gmail.com relationship, or between family members. It can affect anyone regardless of his or her gender or sexuality. The violence can be psychological, physical, sexual, or emotional' (Home Office 2008).

Domestic violence occurs across society, regardless of age, race, sexuality, gender identity, religion, wealth and geography.

The number of women who experience domestic violence over their life time was estimated to be one in four. In Europe, 6 to $10 \%$ of women suffer from domestic violence in 2002 (Council of Europe, 2002).

The relationship between the effects of domestic violence, physical and mental well-being is well documented. Psychological and physical effects of abuse can be felt for many years often with the continuation of psychological/mental health issues, chronic physical health problems as well familial and socioeconomic impacts. $^{1}$

Domestic violence among women in India is considered to be endemic and widespread. ${ }^{2}$ According to the department for women and child development approximately $70 \%$ of women in India are victims of domestic violence. $^{3}$

This all occurs despite the fact that women in India are legally protected from domestic abuse under the Protection of Women from Domestic Violence Act. ${ }^{4}$

Domestic violence often happens in India as a result of dowry demands. ${ }^{5}$ A research was carried out by Srinivasan (2005), who had pointed out that there is a negative correlation between dowry amount and interspousal violence which indicates dangers of a wife falling short on dowry payments or expectations. ${ }^{6}$

It was found that in 2010 there was a steep rise of 1396 deaths due to dowry as compared to 1997 report (Indian dowry death on rise). ${ }^{7}$ In Indian culture, acceptance of dowry and craving for a male child in the family is very common. If not satisfied could lead to abuses.

Seventy-five percent of physical injuries in domestic violence incidents are to the head, neck, and/or mouth. Dental professionals routinely assess the head, neck and mouth areas of their patients and are in a perfect position to identify and treat injuries caused by domestic violence. Violence, abuse, or neglect can present in the oral cavity or perioral areas in a variety of ways. Any oral lesion, tooth 
or soft-tissue injury could be caused by violence. Dental neglect may be an indicator of domestic violence. Patients experiencing domestic violence may be restricted by their abuser from seeking help or contact with friends and family members or from seeking dental or medical care. ${ }^{8}$

The effects of violence on a victim's health are severe. Battered women may suffer from psychosomatic symptoms, and eating problems, chronic pain, gastrointestinal disorders. According to a US study, gynecological problems is more noticed in women who experience intimate partner abuse than non-abused women. ${ }^{9}$

\section{Aims and Objective}

A study was carried out aiming at assessment of the prevalence of domestic violence in Jodhpur. This study had a twin objective of determining:

- The prevalence of domestic violence and to know the impact of the same on the oral health.

- To identify the various risk factor for domestic violence.

\section{MATERIALS AND METHODS}

\section{Study Design and Study Period}

A cohort cross-sectional study was carried out in high court of Jodhpur, Rajasthan, India among registered victims of domestic violence/family planning for a period of 1 month from 18th January 2014 to 27th February 2014.

\section{Study-Universe}

The study subjects includes all the married women who were registered in the family court and also who were under the counseling of domestic violence organisations -Meera Sansthan

\section{Sample Size and Sampling}

Prevalence rate of domestic violence among women was found to be 51\% according to the Mal Sibsankar, Bhattacharya Prabhat. ${ }^{10}$

$$
\mathrm{n}=\mathrm{p} \cdot \mathrm{q} /(\mathrm{SE})^{2}
$$

The sample was calculated to be $n=148.75$. The total sample for the study was taken to be 150 to avoid error.

\section{METHODOLOGY}

A cross-sectional study was carried out using semistructured open ended questionnaire. A pilot study was conducted on 40 victims to cheque the validity of questionnaire and according to the findings the questionnaire was modified for final study.

Inclusion criteria includes study subjects who were legally married and of age 18 years and above and subjects living with her husband for more than 1 year and have registered case against domestic violence.

Inclusion criteria: Females who had registered in the high court and who gave consent for the participation in study were considered as the study subject. Ethical clearance was obtained from Institutional authority.

All the information gathered was transferred into excel sheet. Suitable statistical software (SPSS version -20) was used. Pearson's Chi-square test and p-value were used to calculated the occurrence and impact of domestic violence on oral health among women.

\section{RESULTS}

The study consisted of 150 domestic violence victims who were registered in the family court and also who were under the counseling of domestic violence organisations.

Out of 150 victims, $81.3 \%$ of study population had some level of education and $18.7 \%$ were uneducated. Sixty-six percent of the study subject resided in the urban area. Among the victims of domestic violence who reported to the family court, $39.3 \%$ of the study population were in the age group 40 years and above, followed by $31.3 \%$ who were in the age group 31 to 40 years (Table 1).

Sixty percent of study population reported that they experienced domestic violence soon after marriage. Among the study subjects $54.7 \%$ reported being abused physically and among them 38.7\% experienced continuous physical assault as compare to $1.8 \%$ who reported to have less of physical assault. 5.3\% reported to be sexually abused. $20.7 \%$ were targeted on head during the violence while $49.3 \%$ of the study population were assaulted badly that they were not able to describe their targeted body part (Table 2).

It was noted that $35.3 \%$ of study population produced a female sibling and $5.3 \%$ delivered a male. $71.3 \%$ of the

Table 1: Demography of the study population

\begin{tabular}{lll}
\hline & $n$ & $\%$ \\
\hline Age statistics & & \\
$18-30$ & 44 & 29.3 \\
$31-40$ & 47 & 31.3 \\
41 and above & 59 & 39.3 \\
Total & 150 & 100.0 \\
& Mean $=2.10$ & SD $=0.825$ \\
Where do you live & & \\
Urban & 99 & 66.0 \\
Rural & 51 & 34.0 \\
Total & 150 & 100.0 \\
Education & & \\
Some level of education & 122 & 81.3 \\
Uneducated & 28 & 18.7 \\
\hline Total & 150 & 100.0 \\
\hline
\end{tabular}

$\mathrm{n}$ : number of study subjects 
Table 2: Distribution of questionnaire according to physical abuse

\begin{tabular}{|c|c|c|}
\hline When did the physical abuse start? & $n$ & $\%$ \\
\hline When we got engaged & 3 & 2.0 \\
\hline When I got pregnant & 29 & 19.3 \\
\hline When my partner was unemployed & 2 & 1.3 \\
\hline When we got married & 90 & 60.0 \\
\hline When the first child was born & 21 & 14.0 \\
\hline None of the above & 3 & 2.0 \\
\hline No physical assault & 2 & 1.3 \\
\hline Total & 148 & 98.7 \\
\hline \multicolumn{3}{|l|}{ What type of abuse have you/do you suffer? } \\
\hline Physical abuse & 82 & 54.7 \\
\hline Sexual abuse & 8 & 5.3 \\
\hline Emotional/ psychological abuse & 30 & 20.0 \\
\hline Verbal abuse & 9 & 6.0 \\
\hline Financial abuse & 21 & 14.0 \\
\hline Total & 150 & 100.0 \\
\hline \multicolumn{3}{|l|}{ What sorts of physical assault have you experienced? } \\
\hline No abuse & 50 & 33.3 \\
\hline Pushing or shoving causing no injury & 4 & 2.7 \\
\hline Pushing or shoving causing injury, e.g. bruising & 13 & 8.7 \\
\hline Hitting, slapping or punching causing no injury & 9 & 6.0 \\
\hline Hitting, slapping or punching causing injury & 27 & 18.0 \\
\hline Kicking & 3 & 2.0 \\
\hline Pulling your hairs & 6 & 4.0 \\
\hline Attempted strangulation & 1 & 0.7 \\
\hline Using an object to harm or hit you & 6 & 4.0 \\
\hline Burning you (e.g. stubbing out cigarette on you & 1 & 0.7 \\
\hline Hot water to scald you, trying to set light to you & 2 & 1.3 \\
\hline Hitting your head or body against wall & 4 & 2.7 \\
\hline All of the above & 24 & 16.0 \\
\hline Total & 150 & 100.0 \\
\hline \multicolumn{3}{|c|}{ Has the physical assaults increased, stayed the same or decreased during your relationship? } \\
\hline Increased & 58 & 38.7 \\
\hline Stayed the same & 45 & 30.0 \\
\hline Not sure & 43 & 28.7 \\
\hline Decreased & 2 & 1.3 \\
\hline No physical assault & 2 & 1.3 \\
\hline \multirow[t]{2}{*}{ Total } & 148 & 98.7 \\
\hline & 150 & 100.0 \\
\hline \multicolumn{3}{|c|}{ What part of your body was targeted during the physical assault? } \\
\hline Head & 31 & 20.7 \\
\hline Arms and hands & 22 & 14.7 \\
\hline Genitalia (e.g. breast and crotch area for women) & 1 & 0.7 \\
\hline Torso & 1 & 0.7 \\
\hline Legs and feet & 21 & 14.0 \\
\hline Not sure & 74 & 49.3 \\
\hline Total & 150 & 100.0 \\
\hline \multicolumn{3}{|c|}{ Have you ever tried defending yourself from a physical assault? } \\
\hline Yes & 142 & 94.7 \\
\hline No & 8 & 5.3 \\
\hline Total & 150 & 100.0 \\
\hline
\end{tabular}

$\mathrm{n}$ : Number of study subjects

victims children have witnessd their mothers being abused. $25.3 \%$ of the siblings suffered physical abuse out of which $11.3 \%$ required medical intervention and $14.0 \%$ of children were abused verbally (Table 3).
The victims reported that $54 \%$ of their abusers have the habit of taking alcohol and $24.7 \%$ of the victims claim that they are physically assaulted when their abusers are under the influence of alcohol. The study showed that 
Table 3: Distribution of questionnaire according to child abuse

\begin{tabular}{|c|c|c|}
\hline Is your child a girl or a boy? & $N$ & $\%$ \\
\hline Girl & 53 & 35.3 \\
\hline Boy & 8 & 5.3 \\
\hline Both & 51 & 34.0 \\
\hline No child & 38 & 25.3 \\
\hline \multirow[t]{2}{*}{ Total } & 112 & 74.7 \\
\hline & 150 & 100.0 \\
\hline \multicolumn{3}{|l|}{$\begin{array}{l}\text { Did the children witness (heard or saw) } \\
\text { any abuse on you from your partner? }\end{array}$} \\
\hline Yes & 107 & 71.3 \\
\hline No & 5 & 3.3 \\
\hline No child & 38 & 25.3 \\
\hline \multirow[t]{2}{*}{ Total } & 112 & 74.7 \\
\hline & 150 & 100.0 \\
\hline \multicolumn{3}{|l|}{ Did your partner abuse the children? } \\
\hline Yes & 38 & 25.3 \\
\hline No & 74 & 49.3 \\
\hline No child & 38 & 25.3 \\
\hline \multirow[t]{2}{*}{ Total } & 112 & 74.7 \\
\hline & 150 & 100 \\
\hline \multicolumn{3}{|l|}{$\begin{array}{l}\text { If so, what sort of abuse did your children } \\
\text { suffer? }\end{array}$} \\
\hline Verbal abuse & 21 & 14.0 \\
\hline Emotional abuse & 1 & 0.7 \\
\hline $\begin{array}{l}\text { Physical abuse requiring medical } \\
\text { treatment }\end{array}$ & 17 & 11.3 \\
\hline $\begin{array}{l}\text { Physical abuse not requiring medical } \\
\text { treatment }\end{array}$ & 2 & 1.3 \\
\hline Not abused & 71 & 47.3 \\
\hline No child & 38 & 25.3 \\
\hline \multirow[t]{2}{*}{ Total } & 112 & 74.7 \\
\hline & 150 & 100.0 \\
\hline
\end{tabular}

$\mathrm{n}$ : Number of study subjects

Table 4: Distribution of questionnaire according to factors influencing violence

\begin{tabular}{lll}
\hline Was your abuser an alcoholic? & $n$ & $\%$ \\
\hline Yes & 81 & 54.0 \\
No & 69 & 46.0 \\
Total & 150 & 100.0 \\
While the time of violence was your abuser & & \\
Drunk & 37 & 24.7 \\
Influenced by mother in law & 64 & 42.7 \\
Influenced by some other factor & 49 & 32.7 \\
Total & 150 & 100.0 \\
Is your partner is an employed or not? & & \\
Employed & 106 & 70.7 \\
Unemployed & 44 & 29.3 \\
Total & 150 & 100.0 \\
\hline
\end{tabular}

$\mathrm{n}$ : Number of study subject

mother in law influenced her abuser son to initiate the act of violence as reported by $42.7 \%$ of the victims. $29.3 \%$ of the abusers are unemployed (Table 4).

The study shows that $85.3 \%$ of the victims never came forward to report their sufferings at the initial stages of their married life. The various reasons stated by the
Table 5: Distribution of questionnaire according to filling complain against abuse

\begin{tabular}{lll}
\hline $\begin{array}{l}\text { Did you immediately report after being } \\
\text { abused? }\end{array}$ & $n$ & $\%$ \\
\hline Yes & 22 & 14.7 \\
No & 128 & 85.3 \\
Total & 150 & 100.0 \\
If no, what is the reason after it? & & \\
Society & 69 & 46.0 \\
Waiting patiently & 49 & 32.7 \\
Unable to bear legal expenses & 7 & 4.7 \\
Unable to meet home expense with family & 3 & 2.0 \\
support & & \\
Said yes & 22 & 14.7 \\
Total & 128 & 85.3 \\
& 150 & 100.0 \\
Where did you get the support? & & \\
Family & 127 & 84.7 \\
Friend & 3 & 2.0 \\
Police & 19 & 12.7 \\
DV organization & 1 & 0.7 \\
Total & 150 & 100.0 \\
\hline
\end{tabular}

$\mathrm{n}$ : Number of study subjects

Table 6: Distribution of questionnaire according to occurrence of trauma/injury

\begin{tabular}{lll}
\hline $\begin{array}{l}\text { Have you ever sustained an injury to the } \\
\text { head, neck, or mouth as a result of abuse? }\end{array}$ & $n$ & $\%$ \\
\hline Yes & 124 & 82.7 \\
No & 26 & 17.3 \\
Total & 150 & 100.0 \\
Yes, what sort of injury did this involve? & & \\
Facial injury & 124 & 82.7 \\
No facial injury & 26 & 17.3 \\
Total & 150 & 100.0 \\
\hline
\end{tabular}

$\mathrm{n}$ : Number of study subjects

victims in the delay in expressing their sufferings were to maintain status in the society according to $46.0 \%$, while $32.7 \%$ prefered to wait patienlty in silence fearing social stigma for the victim and her family. The study showed that $84.7 \%$ of the present study population got support from their family (Table 5).

It was noted that $82.7 \%$ of the victims sustained injury to the head of which $17.3 \%$ reported facial injury. However, none of them approached a dental surgeon (Table 6).

Thirty-three percent of victims had girl child and of which $18 \%$ of girls were abused by the abuser. Ten percent of the girl sibling experienced physical assault by the abuser and required medical intervension. The result was not statistically significant (Table 7).

$67.8 \%$ of the uneducated victims were abused physically. $77.3 \%$ of victims who obtained some level of education delayed in reporting to the domestic violence organization as compared to $1 \%$ of illiterate and the results were found to be statistically significant $(p=0.054)$. In order to 
Table 7: Association between physical abuse and gender discrimination

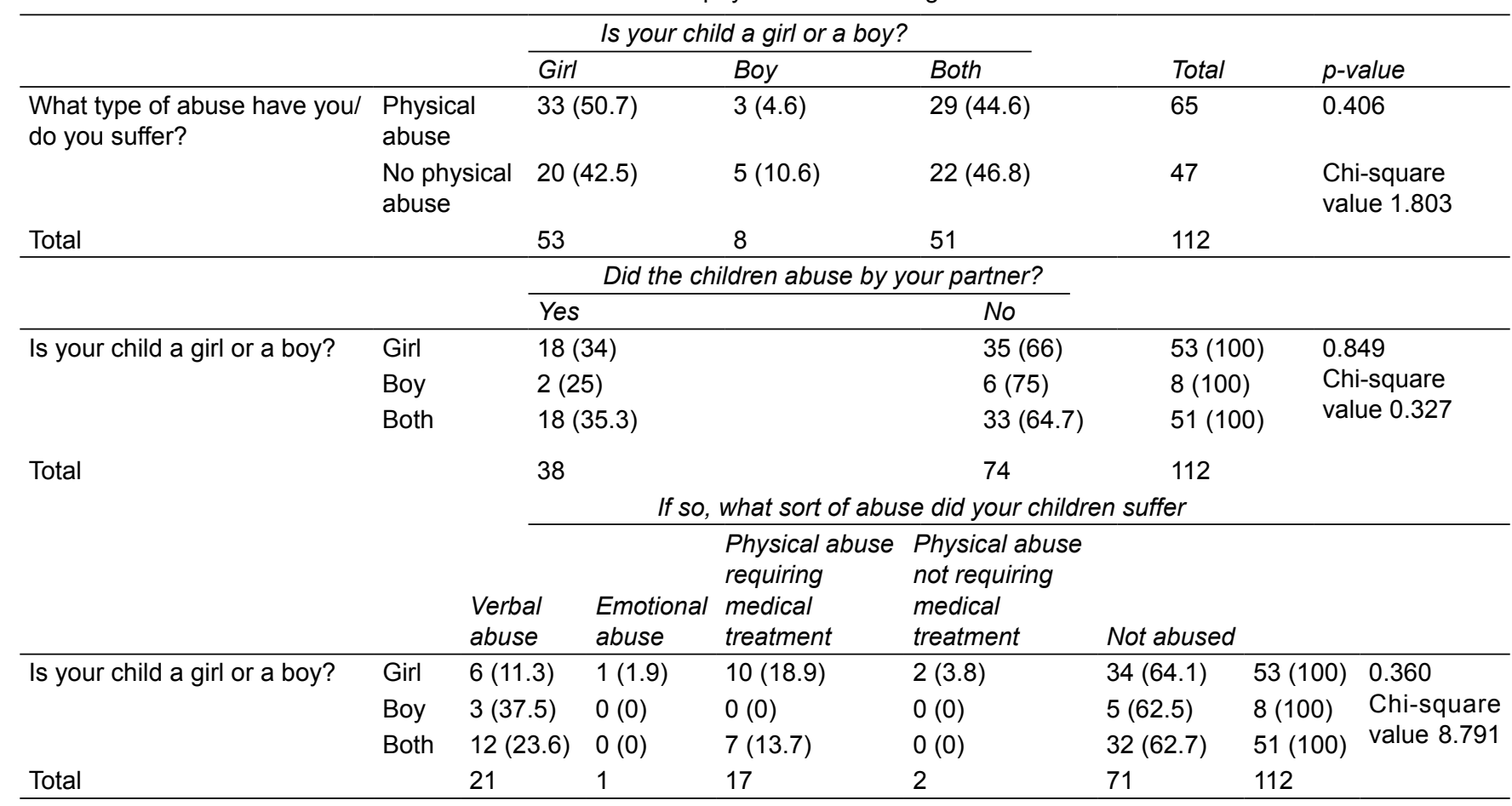

Table 8: Association between education and report against abusement

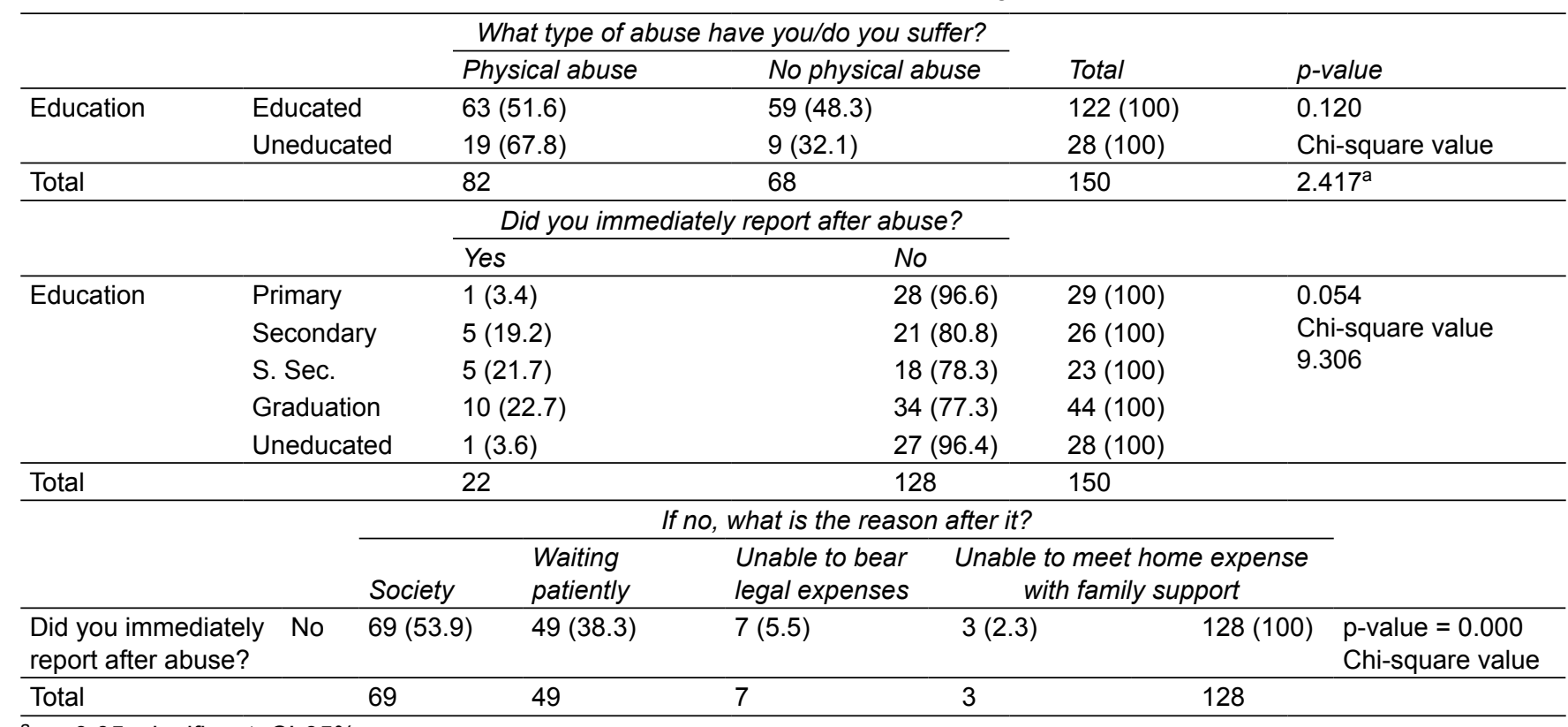

$\mathrm{a}_{\mathrm{p}} \geq 0.05$, significant, $\mathrm{Cl}-95 \%$

maintain the victims status in the society ${ }^{*} 52.9 \%$ of study victims delayed in complaining their sufferings (Table 8).

Sixty-one percent of victims were physically abused by their alcoholic abuser. In the influence of alcohol, $30.4 \%$ of study victims is abused physically whereas $47.6 \%$ of victims is abused physically under the influence of mother-in-law and it is found not to be statistically significant ( $p$ - 0.007), influenced by some other factor like greed for the money from the victim side and the burden of existing girl child are least responsible for physical abuse (21.9\%) among study victims (Table 9).

\section{DISCUSSION}

The study subjects included 150 victims of domestic violence who attended the Jodhpur High court; in the state of Rajasthan, North West of India. The victims who were willing to take part in this cross-sectional study during the period from mid of January to the end of February 2014 were included in the study. A pilot study was completed to know the validity and reliability of the study. Based on the pre-tested pilot study, the questionnaire was modified to include the type and extend of different types of domestic violence and to 
Table 9: Association between physical abuse and various influencing factors

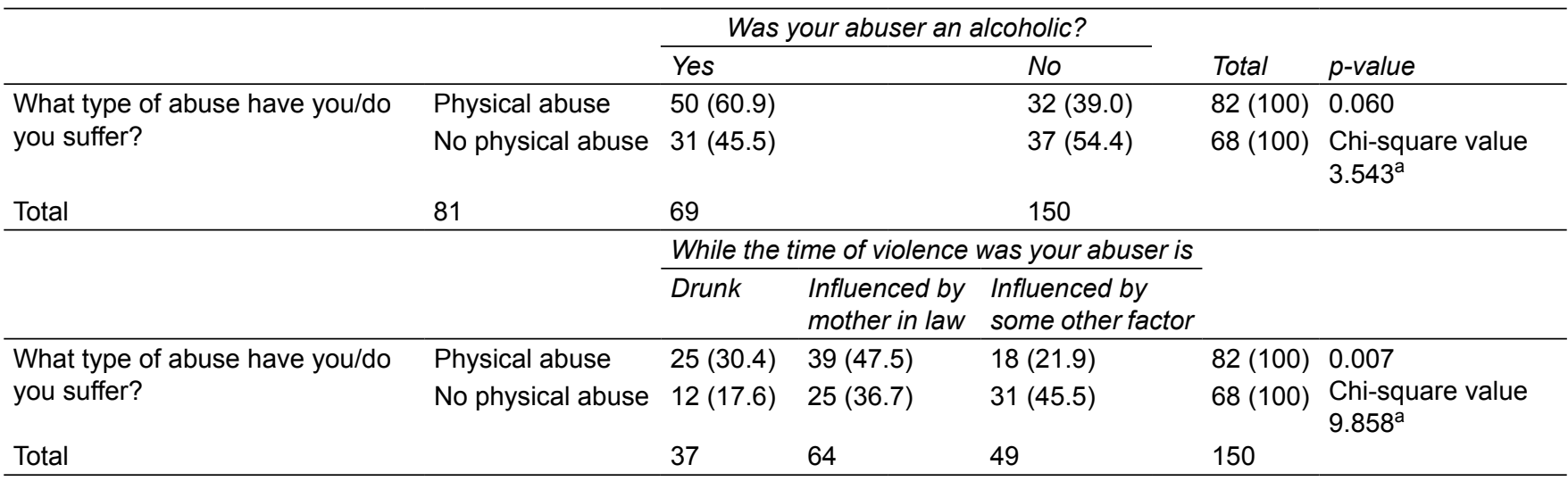

${ }_{\mathrm{a}} \geq 0.05$; siginificant, $\mathrm{Cl}-95 \%$

identify probable reasons for domestic violence against married women who had registered in the court.

It was observed from the present study that the most common age group for abused women was 40 years and above followed by 30 to 40 years. Similar finding was also shown by Mishra et $\mathrm{al}^{11}$ and $\mathrm{K}$ Yoshikawa et al. ${ }^{12}$ But contradictory finding was revealed by $\mathrm{M}$ Mahapatro et al. ${ }^{13}$

In the present study, the most common type of violence was physical violence followed by emotional violence. The study results showed similarity to a study carried by Mishra et al. ${ }^{11}$ However in a multicentered study by WHO reported that physical violence followed by sexual violence was common. ${ }^{14}$ In the pretested questionnaire of the present pilot study, the study participants were shy to respond to questions related to sexual abuse.

According to the level of education was it was found that the prevalence of domestic violence is least among graduates. A study carried out by Mishra et al and Kimuna et $\mathrm{al}^{11,15}$ in India reported similar findings. The level of education of the victim could be a beneficial factor against domestic violence. The present study also showed a strong association between alcohol intake and physical violence ( $\mathrm{p}$-value 0.007). The results also show that the victim's mother-in-law initiated the act of physical violence. Research carried out by Babu and Kar observed that women reported involvement of husband's parents in most of the physical violence cases. ${ }^{16}$ The odds of experiencing physical and sexual violence among the victims were observed by studies done by Kimuna to be higher among husbands who were drunkard. Studies carried out nationally as well as internationally showed the same trend. ${ }^{17-21}$

In the present study, $71.5 \%$ of children witnessed violence on their mother and similar observation was also recorded by Kupper LL et al. ${ }^{22}$

Eighteen percent reported the most common form of physical violence was hitting on the head, slapping or punching on the face causing injury. Pushing or shoving causing bruises were reported by 8.7 and $4 \%$ suffered object throwing which were reported by similar studies. ${ }^{23}$ According to NFHS III the most common physical violence was slapping seen among $34 \%$ of the study subjects followed by twisting of arms or pulling of hairs $(15.4 \%)$, throwing hard objects (14\%), kicking $(12 \%)$ and choking seen among $2 \%{ }^{24}$

$82.7 \%$ of the study victims reported the facial injury which is almost similar to the finding of the study done by Bach $\mathrm{T}$ Le et al in which majority (81\%) of victims presented with maxillofacial injuries.

Abused women most often seek help from their own families. In our study $84.7 \%$ women sought help from their parents, followed by $12.7 \%$ reported to police while only $2.0 \%$ sought help from their relative which represented the tip of the iceberg. A similar study at North Benga ${ }^{25}$ revealed that $74.9 \%$ never sought for any help; $13.9 \%$ sought for first aid, $4.9 \%$ sought for professional help, 3.6\% reported to police and the NFHS III data also corroborated with the above finding. Notably few women experiencing domestic violence seek help from any institutional sources, such as the police, medical personnel or social service organizations. ${ }^{24}$

In the five state study, among the respondents who sought help, 26.3\% abused women had approached their parents, $15.6 \%$ to relatives and $57.9 \%$ to friends. ${ }^{23}$ Goa study revealed that $31.1 \%$ talked to relatives or close friends and only $4.4 \%$ took legal help. ${ }^{26}$ In the Bangalore study, nobody informed the police. ${ }^{27}$ This was because women were socialized to accept, tolerate and even rationalize domestic violence, and to remain silent about such experiences who wait patiently in silence fearing social stigma for her and her family. Often, they had the idea that it belonged to their husbands' right to beat their wives. Many victims witnessed in their childhood their parents being abused and felt the notion that it is the right of their husbands to beat their wives. This could 
be one of the reasons that some of them suffered silently. However in the present study many victims suffered abuses silently due to social stigma and after a point of intolerance have finally approached the court.

\section{CONCLUSION}

In the present study, prevelance of abuse was noticed more in the educated group inspite of belief that education is an important beneficial factor to prevent violence thus it contradicts the statement. Whereas, study done by Kimuna et al, ${ }^{15}$ Mishra et al $^{11}$ observed that there was a strong association between the literacy status and vulnerability towards abusement. Thus we can not state that education is one of the protective factors from domestic violence.

In the present study, the reason for not reporting about abuse or delay in expressing their sufferings were to maintain status in the society and preffered to wait patienlty in silence fearing social stigma for the victim and her family, there is no other studies who have identified these factors.

\section{REFERENCES}

1. Domestic violence victims. Available at: http://www.teesjsna. org.uk/redcar-domestic-violence-victims/. [Accessed 10th April 2014].

2. Ganguly, Sumit. 'India's Shame'. The Diplomat. Retrieved 27 April 2012.

3. Chowdhury, Renuka. 'India tackles domestic violence'. BBC 26 October 2006.

4. 'India tackles domestic violence'. BBC News. 2006-10-27. Retrieved 25 April 2012.

5. 'A situational analysis of domestic violence against women in Kerala'. Kochi: Rajagiri College of Social Sciences. September 2005. Retrieved 25 April 2012.

6. Srinivasan, Sharada, Bedi A. 'Domestic Violence and Dowry: Evidence from a South Indian Village.' World Development 35 (2007). 18 Mar. 2013.

7. Bedi R. 'Indian Dowry Deaths on the Rise.' The Telegraph [New Delhi] 27 Feb. 2012.

8. MaryLou Austin, RDH, MS. The Academy of Dental Learning \& OSHA Training (800) 522-1207.

9. Shane B, Ellsberg M. 'Violence Against Women: Effects on Reproductive Health (Outlook, 20:1).

10. Sibsankar M, Prabhat B. Prevalence of domestic violence and its effects on reproductive health of women in India. International Journal of Physical and Social Sciences Year: 2013;3:197-204.

11. Mishra A, Patne SK, Tiwari R, Srivastava DK, Gour N, Bansal M. A cross-sectional study to find out the prevalence of different types of domestic violence in Gwalior city and to identify the various risk and protective factors for domestic violence Year: 2014;39:21-25.

12. Yoshikawa K, Agrawal NR, Poudel KC, Jimba M. A lifetime experience of violence and adverse reproductive outcomes:
Findings from population surveys in India. Biosci Trends 2012;6:115-121.

13. Mahapatro M, Guptal RN, Gupta V. The Risk Factor of Domestic Violence in India. Indian Journal of Community Medicine J 2012;37:153-157.

14. World Health Organization. Who Multi-Country Study on Women's Health and Domestic Violence against Women: Initial Results on Prevalence, Health Outcomes and Women's Responses. Geneva: WHO; 2005.

15. Kimuna SR, Djamba YK, Ciciurkaite G, Cherukuri S. Domestic violence in India: Insights from the 2005-2006 national family health survey. J Interpers Violence 2013; 28:773-807.

16. Babu BV, Kar SK. Domestic violence against women in eastern India: A population-based study on prevalence and related issues. BMC Public Health 2009;9:129.

17. Shrivastava PS, Shrivastava SR. A study of spousal domestic violence in an urban slum of Mumbai. Int J Prev Med 2013; 4:27-32.

18. Sinha A, Mallik S, Sanyal D, Dasgupta S, Pal D, Mukherjee A. Domestic violence among ever married women of reproductive age group in a slum area of Kolkata. Indian J Public Health 2012;56:31-36.

19. Stuart GL, Moore TM, Ramsey SE, Kahler CW. Hazardous drinking and relationship violence perpetration and victimization in women arrested for domestic violence. J Stud Alcohol 2004;65:46-53.

20. Stuart GL, Moore TM, Elkins SR, O'Farrell TJ, Temple JR, Ramsey SE, et al. The temporal association between substance use and intimate partner violence among women arrested for domestic violence. J Consult Clin Psychol 2013;81:681-690.

21. Tran TD, Tran T, Wynter K, Fisher J. Interactions among alcohol dependence, perinatal common mental disorders and violence in couples in rural Vietnam: A cross-sectional study using structural equation modeling. BMC Psychiatry 2012;12:148.

22. Martina SL, Moracco KE, Garrod J, Tsuia AO, Kupperd LL, Chasea JL, Campbell JC. Domestic violence across generations: findings from northern India. International Journal of Epidemiology; 31:560-572.

23. Yugantar Education Society, Civil Lines, Sadar, Nagpur. Research study report: A study of nature, extent, incidence and impact of domestic violence against women in the states of Andhra Pradesh, Chhattisgarh, Gujarat, Madhya Pradesh and Maharashtra. Submitted to Planning Commission, Government of India, New Delhi, 2003.

24. International Institute for Population Sciences (IIPS) and Macro International. National Family Health Survey (NFHS3), 2005-06: India: Volume I. Mumbai: IIPS, 2007.

25. Ray K, Chakraborty M, Roy H, Gupta S, Baner-jee I. 'Violence against Women': Evidence from a Cross Sectional Study in Urban Area of North Bengal. Al Ameen J Med Sci 2012;5: 157-164.

26. Kamat U, Ferreira AMA, Motghare DD, Kamat N, Pinto NR. A cross-sectional study of physical spousal violence against women in Goa. Health Line 2010;1:34-40.

27. Gaikwad V, Madhukumar S, Sudeepa D. An epidemiological study of domestic violence against women and its association with sexually transmitted infections in Bangalore Rural. Online J Health Allied Sci 2011;10:1-3. 